\title{
MEMADUKAN RUKYATULHILAL DENGAN PERKEMBANGAN SAINS
}

\author{
Ahmad Junaidi \\ Institut Agama Islam Negeri (IAIN) Ponorogo \\ Jl. Pramuka No. 156, Ronowijayan, Ponorogo, Jawa Timur \\ E-mail: ahjunaidi@gmail.com
}

\begin{abstract}
Integrating Rukyatulhilal with the Development of Science. Hilal (the crescent moon) which is a parameter to determine the begining of the month is a very thin and dim objects. The testimony of sighting it as the basis for the stipulation of the early month of hijri calendar is still frequently subjected to subjectivity. On the other hand, the demand of objectivity as the basic of islamic worshiping is a necessity. The oath enacted against the moon lunar sighting is the only way to assess the objectivity of the witness. Witness in the testimony of sighting the crescent moon must meet some requirements. But what often happens in the field is that there is rarely any assessment of the witness whether it meets the requirements or not. Assessing the honesty and fairness of a witness is not easy. So the development of science and technology is expected to be able to improve the objectivity of sighting the crescent moon, so the results can be accounted for by islamic law and science. Optical and digital imaging technology is one of the bids to increase the objectivity of sighting the crescent moon.
\end{abstract}

Keywords: sighting the crescent moon; testimony of sighting; digital imaging.

\begin{abstract}
Abstrak: Memadukan Rukyatulhilal dengan Perkembangan Sains. Hilal yang menjadi parameter dalam penentuan awal bulan merupakan obyek yang sangat tipis dan redup. Kesaksian melihatnya yang menjadi dasar penetapan awal bulan hijriah masih sering diwarnai subyektifitas. Di sisi lain tuntutan obyektifitas terhadap dasar ibadah memang sebuah keniscayaan. Sumpah yang diberlakukan terhadap saksi ketampakan hilal merupakan satusatunya jalan untuk membuktikan obyektifitas saksi. Saksi dalam syahâdah rukyatulhilal harus memenuhi beberapa persyaratan. Namun yang sering terjadi di lapangan jarang sekali ada penilaian terhadap saksi apakah sudah sesuai dengan persyaratan atau tidak. Menilai kejujuran saksi dan sifat 'adâlahnya memang bukan mudah. Maka perkembangan sains diharapkan dapat menjadi sarana untuk meningkatkan obyektifitas rukyatulhilal, sehingga hasil dari rukyatulhilal bisa dipertanggungjawabkan secara syariah dan ilmiah. Teknologi optik dan digital imaging merupakan salah satu tawaran untuk meningkatkan obyektifitas rukyatulhilal.
\end{abstract}

Kata kunci: rukyatulhilal; syahâdah; digital imaging.

\section{Pendahuluan}

Rukyatulhilal merupakan salah satu cara dalam menentukan datangnya hari baru dalam kalender hijriah.' Cara ini sudah dipraktekkan umat Islam sejak masa Nabi Saw sesuai petunjuk beliau, dan hal ini legitimasi dan dalil terhadap model penentuan kalender ini. ${ }^{2}$ Cara lain dalam menentukan awal

${ }^{1}$ Susiknan Azhari, Ensiklopedi Hisab Rukyat, (Yogyakarta: Pustaka Pelajar, 2008), h. 183; Muhyiddin Khazin, Kamus Ilmu Falak, (Yogyakarta: Buana Pustaka, 2005), h. 69; Muhammad bin Abî Bakr al Râzî, Mukhtâr al-Sihâh, (Kairo: Dâr al-Hadîs,, 2003), h. 133.

${ }^{2}$ Abd. Salam, Penentuan Awal Bulan Islam dalam Tradisi Figh Nahdlatul Ulama, (Surabaya: Pustaka Intelektual, 2009), h. 43 . bulan adalah dengan perhitungan astronomis terhadap posisi hilal, yang dikenal dengan hisab. ${ }^{3}$ Baik rukyat maupun hisab mempunyai tujuan yang sama, yakni untuk mengetahui keberadaan hilal. Hilal dalam hal ini adalah parameter dalam memulai awal bulan Hijriah.

Hilal merupakan bulan sabit yang sangat tipis yang diamati pertama kali pasca konjungsi. ${ }^{4}$ la

${ }^{3}$ Badan Hisab dan Rukyat Departemen Agama, Almanak Hisab Rukyat, (Jakarta: Direktorat Bimbingan Masyarakat Islam Kementerian Agama RI, 2010), h. 20.

4 Moedji Raharto, "Teknologi Optik sebagai Pembantu Penetapan Awal Bulan Hijriah/Qamariyah," dalam Hisab Rukyat dan Perbedaannya, ed. oleh Choirul Fuad Yusuf, (Jakarta: 
merupakan obyek yang sangat sulit diamati, sebab tingkat kecerlangan bulan sabit pada fase tersebut hampir sama dengan kecerlangan cahaya senja yang dihamburkan oleh atmosfir bumi. Sehingga mengenali obyek hilal dengan pasti membutuhkan sebuah keseksamaan. Sering kali obyektifitas dikalahkan oleh halusinasi dan kesalahan dalam usaha mengidentifikasi keberadaan hilal, sehingga melihat dan mengidentifikasi hilal ini sering kali menjadi sesuatu yang subyektif. Subyektifitas hasil rukyatulhilal sering kali ditemui dalam kegiatan rukyatulhilal yang hanya mengandalkan ketajaman mata.

Subyektifitas hasil kegiatan rukyatulhilal bisa dilihat dari beberapa hal, antara lain: 1. klaim-klaim keberhasilan rukyat, padahal saat pelaksanaan rukyat kondisi ufuq/horizon mendung sehingga terbenamnya matahari tidak bisa terlihat apalagi hilal yang sinarnya sangat lemah dan tipis. 2. Pernyataan keberhasilan rukyat, padahal pada saat itu hilal sudah terbenam. 3. Laporan keberhasilan rukyat pada posisi ketinggian hilal yang kritis/belum imkân al-ru'yah. 4. Laporan keberhasilan rukyat tetapi bertentangan dengan data perhitungan astronomis, baik posisi maupun ketinggiannya.

Perkembangan teknologi optik dan fotografi digital diharapkan bisa diadopsi dan dimanfaatkan semaksimal mungkin dalam kegiatan rukyatulhilal, sehingga diharapkan bisa meningkatkan obyektifitas pelaksanaan dan hasil kegiatan rukyatulhilal, bahkan menepis subyektifitas yang masih sering terjadi dalam kegiatan rukyatulhilal. Bagaimana aplikasi dari teknologi tersebut dalam kegiatan rukyatulhilal dan bagaimana hasil yang didapatkan akan dibahas dalam artikel ini.

\section{Rukyatulhilal}

Rukyatulhilal adalah kalimat serapan dari bahasa Arab yang terdiri 2 kata yakni "rukyat" dan "hilal" yang menjadi satu kesatuan makna, yang dalam bahasa Arab disebut mudhâf dan mudhâf ilayh. Rukyatulhilal menjadi salah satu teknik di dalam penentuan kalender hijriah. Untuk mengetahui lebih rinci pengertian

Puslitbang Kehidupan Beragama Badan Litbang Agama dan Diklat Keagamaan Departemen Agama RI, 2004), h. 146. rukyatulhilal perlu dijelaskan masing-masing kata tersebut:

\section{Rukyat}

Kata rukyat (رؤية) adalah bentuk mashdar/ kata benda dari kata kerja ra'â (رأى) / melihat. Kata ra'â (رأى) mempunyai murâdif/sinonim dan makna yang bermacam-macam, antara lain:

- نظر yang bermakna melihat; 5

- بصر بang bermakna memandang; ${ }^{6}$

- $\quad$ أدرك yang juga bermakna mengerti;

- $\quad$ yang bermakna menduga, mengira. ${ }^{8}$

Kalau ditelusuri lebih jauh lagi, kata ra'â (رأى) juga memiliki beberapa bentuk mashdar/kata benda dengan arti yang berbeda-beda. Bentukbentuk mashdar dari kata ra'â antara lain:

- Rukyat (رؤية) yang berarti “ "النطر بالعين والقلب ” yakni melihat dengan mata atau dengan hati;9

- Ra'yan (رأيا) yang berarti praduga, pendapat, prasangka; ${ }^{10}$

- Ru’ya (رؤيا) yang artinya “ما تراه في المنام" yakni mimpi."

Pemilihan makna secara etimologis akan berdampak kepada pengertian secara terminologis. Kata ra'â dan tashrîf-nya ketika dirangkaikan dengan objek (maf'ûl bih) yang fisikal (tabîîyat) menggunakan mashdar ru'yatun (رؤية) yang mempunyai arti tunggal yaitu melihat dengan mata kepala, baik dengan mata telanjang maupun dengan alat, sedangkan ra'â yang memiliki arti lain objeknya tidak fisikal dan kadang tanpa objek serta masdarnya bukan ru'yatun, melainkan ra'yan dan kadang ru'ya yang bermakna mimpi. ${ }^{12}$

\footnotetext{
${ }^{5}$ Ahmad Warson Munawwir, al-Munawwir Kamus ArabIndonesia, (Surabaya: Pustaka Progresif, 1997), h. 460.

${ }^{6}$ Ahmad bin Muhammad bin 'Alî al-Maqrî al-Fayyûmî, alMisbâh al-Munîr fî Gharîb al-Syarh al-Kabîr li al-Râfi'î, (Beirut: alMaktabah al-'llmîyah, tt), h. 247.

7 Abû Hilâl al-hasan bin 'Abdillâh bin Sahal bin Sa'îd bin Yahyâ bin Mahrân al-'Askarî, Mu'jam al-Furûq al-Lughawîyah, (Muassasah al-Nasyr al-Islâmî, 1412), h. 543.

${ }^{8}$ Ahmad Warson Munawwir, al-Munawwir..., h. 460.

9 Ibnu Manzûr, Lisân al-'Arab, (Kairo: Dâr al-Ma'ârif, tt), vol. 17. h. 1537.

${ }^{10}$ Atabik Ali dan Ahmad Zuhdi Muhdlor, Kamus Kontemporer Arab-Indonesia, (Yogyakarta: Multi Gaya Grafika, 1998), h.950.

"Louis Ma'luf, al-Munjid fî al-Lughah wa al-A'lâm, (Beirut: Dâr al-Masyriq, 1989), h.243.

${ }^{12} \mathrm{~A}$. Ghazali Masroerie, Penentuan Awal Bulan Qamariyah, (Jakarta: Lajnah Falakiyah Nahdlatul Ulama, 2011), h. 2.
} 


\section{Hilal}

Kata "الهلال" secara etimologi bermakna “غرّة القمر" (permulaan bulan). Kata tersebut me-

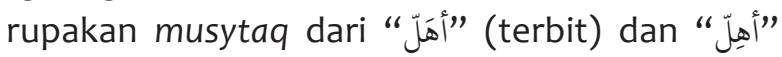
(Sesuatu yang terlihat). ${ }^{33}$ Menurut sebagian ulama, bentuk ketampakan bulan yang pertama kali itu disebut hilal karena ketampakannya setelah sembunyi/tidak tampak. ${ }^{14}$ Menurut ulama yang lain, dinamakannya hilal disebabkan ketika melihatnya, orang-orang mengeraskan suaranya/ histeris dengan membaca tahlil/yuhillu. ${ }^{15}$

Kata hilal disebutkan dalam bentuk jama'/ plural dalam al-Qur'an surat al-Baqarah 189:

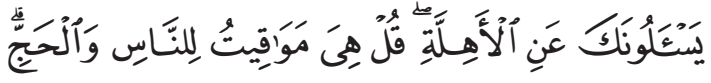

Mereka bertanya kepadamu tentang bulan sabit. Katakanlah: Bulan sabit itu adalah tanda-tanda waktu bagi manusia dan (bagi ibadat) haji; (Q.S. al-Baqarah [2]: 189)

Penyebutan hilal dengan "ahillah" dalam berbentuk jama' (plural), mengindikasikan bahwa bentuk bulan yang seperti itu tidak hanya sekali dalam satu siklus pergerakannya. Sehingga Wahbah al-Zuhaylî mendefinisikan hilal adalah bulan yang tampak sangat tipis pada dua atau tiga malam pertama di setiap awal bulan dan itu akan kembali terjadi pada akhir bulan. ${ }^{16}$

Hilal dipahami sebagai bulan yang tampak cahanya dalam bentuk seperti tandan yang tua, atau sering disebut seperti sabit, sehingga ada yang menyebut bulan sabit. Ketampakan hilal tersebut menunjukkan bahwa definisi hilal itu mengacu kepada fenomena observasi (rukyat), meskipun secara hisab fase-fase/manzilah bulan (termasuk fase pertama, yakni hilal) bisa dihitung. ${ }^{17}$ Pemahaman seperti ini mengacu pada surat Yasin ayat 39:

${ }^{13}$ Abû al-Qâsim Ismâ'îl bin 'Ubbâd bin al-'Abbâs bin Ahmad bin Idrîs al-Tâliqânî, al-Muhîth fî al-Lughah, (Beirut: 'Alim al-Kutub, 1994), vol. 3, h.322.

${ }^{14}$ Wahbah bin Musthafâ al-Zuhaylî, al-Tafsir al-Munîr fî al'Aqîdah wa al-Syarî'ah wa al-Manhaj, (Damaskus: Dâr al-Fikr alMu'âsir, 1418), vol. 2, h. 169 .

${ }^{15}$ Muhammad Mutawallî al-Sya'râwî, Tafsîr al-Sya'râwî, (Akhbâr al-Yawm, 1991), vol. 2, h. 808.

${ }^{16}$ Wahbah bin Musthafâ al-Zuhaylî, al-Tafsir al-Munîr..., h. 169.

${ }_{17}$ Thomas Djamaluddin, Astronomi memberi Solusi Penyatuan Ummat, (Jakarta: Lembaga Penerbangan dan Antariksa Nasional, 2011), h. 5.

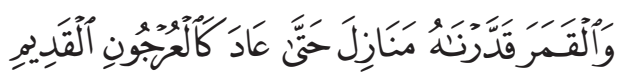

Dan telah Kami tetapkan bagi bulan manzilahmanzilah (posisi), sehingga (setelah dia sampai ke manzilah yang terakhir) kembalilah dia sebagai bentuk tandan yang tua. ${ }^{18}$ (Q.S. Yasin/36: 39)

Konsep tentang hilal yang terkait dengan penentuan awal bulan berkembang sejalan dengan perkembangan pemahaman umat Islam terhadap segi-segi astronomis dan segi syar'î kalender tersebut. Menurut teori yang paling tua, hilal adalah bulan sabit yang dapat dilihat pertama kali. Dari dalil-dalil syar'î tentang penggenapan 30 hari umur bulan yang sedang berjalan jika bulan sabit tidak bisa dilihat, diperoleh unsur waktu dari terlihatnya buln sabit tersebut, yakni tanggal 29 petang pasca terbenamnya matahari. Jadi ada dua unsur pokok dalam konsep hilal menurut teori ini, yakni:

1) Bulan sabit yang dapat terlihat;

2) Waktu terlihatnya adalah tanggal 29 petang, pasca terbenamnya matahari.

Konsep hilal seperti ini dipedomani dalam penentuan awal bulan pada masa Nabi Saw, para sahabat dan jumhûr fuqahâ' pada masa berikutnya.

Sejalan dengan perkembangan informasi di bidang astronomi, kaum muslimin mulai mengenal pola pergerakan benda-benda langit. Misalnya bumi bergerak mengelilingi matahari ke arah timur, dan dengan arah yang sama bulan mengitari bumi. Gerakan bumi mengelilingi matahari mengakibatkan efek semu matahari bergerak ke arah timur pada ekliptika sebanyak satu putaran dalam satu tahun. Sedangkan bulan bergerak ke timur sebanyak satu putaran dalam satu bulan. Artinya bulan bergerak ke arah timur lebih cepat dari pada matahari. Pola gerak melingkar dengan kecepatan yang tidak sama tersebut meniscayakan terjadnya moment yang disebut ijtimâ'/konjungsi, yaitu saat bulan berada pada bujur astronomi yang sama dengan matahari. ${ }^{19}$

${ }^{18}$ Maksudnya: bulan-bulan itu pada Awal bulan, kecil berbentuk sabit, kemudian sesudah menempati manzilahmanzilah, Dia menjadi purnama, kemudian pada manzilah terakhir kelihatan seperti tandan kering yang melengkung.

19 Salam, Penentuan Awal Bulan Islam dalam Tradisi Fiqh Nahdlatul Ulama..., h. 41. 
Inilah yang melatar belakangi munculnya teori yang kedua tentang hilal pada aspek waktu, yakni hilal yang dijadikan parameter awal bulan, munculnya setelah terjadinya ijtimâ'. Sehingga kalau terjadi ketampakan hilal pada tanggal 29 petang hari setelah terbenamnya matahari, tetapi pada saat itu belum terjadi ijtimâ', maka hilal yang nampak tersebut dianggap sebagai hilal tua.

\section{Alat Bantu Rukyatulhilal dan Hukum Penggunaannya}

Rukyatulhilal yang bermakna observasi hilal pada petang hari tanggal 29 adalah kegiatan yang sudah dilakukan umat Islam sejak masa Nabi. Sehingga metode inilah yang dianut oleh para mujtahid madhâhib al-arba'ah dan para ulama kontemporer hingga saat ini. Dari penjabaran makna dari kedua kata "rukyat" dan "hilal", maka bisa diambil sebuah pengertian bahwa rukyatulhilal adalah usaha untuk melihat sinar bulan sabit yang dilakukan setelah matahari terbenam pada hari terjadinya ijtimâ'/conjunction. Pada awalnya rukyat hanya sebatas menggunakan mata telanjang, tanpa bantuan alat. Akan tetapi seiring perkembangan ilmu pengetahuan dan teknologi, rukyat-pun mengalami perkembangan dengan menggunakan alat bantu pengamatan, seperti theodolite, binokuler, teleskop dan sebagainya..$^{20}$

Namun penggunaan alat bantu rukyat ini juga menuai perdebatan tentang kebolehannya. Menurut Ibn Hajar al-Haytamî dalam kitab Tuhfah al-Muhtâj (Syarh/penjelasan dari kitab Minhâj alTâlibîn karya Imam Nawawi), penggunaan alat bantu rukyat/nahwu mir'ât (sesuatu yang bisa memantulkan obyek) tidak diperkenankan. Namun beliau tidak meyebutkan alasan tidak diperkenankannya penggunaan alat bantu rukyat. Namun al-Syarwânî dalam kitab Hawâsyî Tuhfah al-Minhâj (penjelasan lebih lanjut dari kitab Tuhfah al-Minhâj) menyatakan lebih utama tidak menggunakan alat bantu rukyat, namun pada dasarnya menurut beliau penggunaan alat bantu rukyat (yang memantulkan obyek, yang mendekatkan dan memperbesar obyek) tetap diperkenankan. ${ }^{21}$

${ }^{20}$ Departemen Agama RI, Pedoman Teknik Ru'yat, (Jakarta: Proyek Pembinaan Badan Peradilan Agama, 1994), h. 2-3.

${ }^{21}$ 'Abd al-Hamîd al-Syarwânî, Hawâsyî Tuhfah al-Muhtâj
Dari dua pendapat di atas, penulis cenderung kepada pendapat yang membolehkan penggunaan alat bantu rukyat, sebab pada dasarnya yang melakukan penilaian terhadap obyek rukyat tetap mata. Alat bantu rukyat hanya bersifat membantu melokalisir dan memperjelas obyek rukyat.

\section{Kesaksian Rukyatulhilal}

Hasil rukyatulhilal yang berupa ketampakan hilal merupakan salah satu pedoman dalam memulai bulan baru dalam kalender hijriah. Dalam beberapa kasus, masuknya bulan baru menjadi pedoman mulainya ibadah. Untuk bisa dijadikan sebagai pedoman mulainya pelaksanaan ibadah, maka dibutuhkan keyakinan yang mendalam terhadap kebenaran hasil rukyatulhilal. Dalam menyikapi hasil rukyatulhilal, Rasul mengambil sumpah terhadap orang yang menyatakan berhasil melihat hilal .

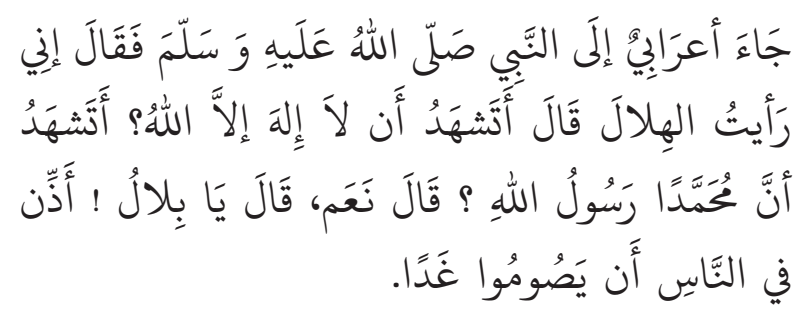

Telah datang seorang Badui kepada Nabi SAW. Dan berkata: Sungguh saya telah melihat hilal. Nabi bersabda: Apakah kamu bersaksi bahwa tidak ada Tuhan selain Allah? Apakah kamu bersaksi bahwa Muhammad utusan Allah? Badui berkata: Ya. Maka Nabi bersabda kepada Bilal: Umumkan kepada semua orang untuk berpuasa mulai besok. (H.R. Tirmiżî, Nasâ'i dan Abû Dâwud).22

Dalam hal itsbât awal bulan, Nabi memang melaksanakan dengan cara yang terlihat sederhana, yakni dengan sumpah. Sepintas apa yang diajarkan Nabi tersebut memang sederhana. Namun kalau dipahami lebih jauh, pengambilan sumpah oleh Nabi kepada orang yang mengaku menyaksikan hilal mengindikasikan bahwa Nabi menghendaki persaksian rukyat yang betul-betul obyektif. Tentu pada saat itu untuk mengukur

bi Syarh al-Minhâj, (Kairo: Mathba'ah Musthafâ Muhammad, t.t.), hal. 372; bandingkan dengan Ahmad Izzuddin, Fiqh Hisab Rukyah, (Jakarta: Erlangga, 2007), vol. 3, h. 6-7.

${ }^{22}$ Al-Tirmîdhî, al-Jâmi' al-Shahîh, (Beirut: Dâr al-Fikr, tt), vol. 3, h. 74; al- Nasâî, Sunan al-Nasâi., (Beirut: Dâr al-Fikr, tt), vol. 4, h. 172; Abû Dâwud, Sunan Abî Dâwud, (Beirut: Dâr al-Fikr, tt), vol. 1, h.715. 
obyektifitas kesaksian tidak ada lain kecuali dengan sumpah. Sehingga pada era berikutnya ulama memberikan syarat bagi orang yang diambil kesaksiannya dengan beberapa kriteria.

Menurut Imam Abû Hanîfah, syahâdah/persaksian terhadap keberhasilan rukyat harus memenuhi persyaratan; 1) Apabila kondisi cuaca cerah, maka persaksian rukyatulhilal harus dilakukan oleh orang dengan jumlah yang banyak. 2) Apabila cuaca tidak cerah/berawan, kesaksian bisa dilakukan oleh satu orang dengan kriteria: muslim, 'âdil, 'âqil, bâligh baik laki-laki maupun perempuan. Sedangkan menurut Imam Mâlik, syahâdah rukyatulhilal harus dilakukan oleh sekumpulan orang/jamaah yang diperkirakan tidak mungkin bohong, meskipun mereka bukan termasuk orang yang 'âdil, atau dilakukan oleh dua orang yang 'âdil. Sedangkan menurut Imam Syâfî̂ dan Imam Ahmad bin Hanbal, syahâdah rukyatulhilal bisa dilakukan oleh seorang laki-laki muslim yang 'âdil, 'âqil, bâligh, merdeka.. ${ }^{23}$

Yang bisa dipahami dari syarat-syarat yang ditentukan oleh para Imam Mazhab ini adalah semangat kehati-hatian dalam menerima kesaksian rukyatulhilal. Kehati-hatian untuk menjamin kebenaran dan obyektifitas rukyatulhilal yang menjadi dasar itsbât awal Ramadan dan Syawwal. Kehati-hatian para ulama ini sebagaimana yang dicontohkan oleh Nabi dalam memulai puasa. Beliau melarang para sahabat untuk berspekulasi melakukan puasa Ramadan sehari atau dua hari sebelum ada kejelasan masuknya bulan Ramadan. Redaksi larangan Nabi tersebut menggunakan nûn tawkîd, yang berarti sifat dari larangan tersebut sangat ditekankan.

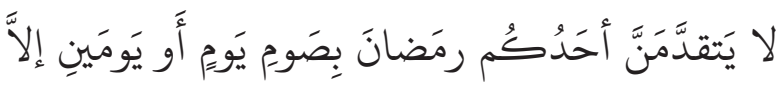

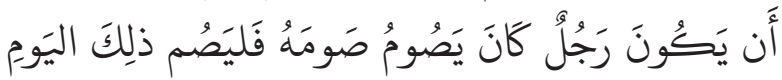
Janganlah sekali-kali seorang di antara kamu memajukan bulan Ramadan dengan puasa sehari atau dua hari sebelumnya, kecuali seseorang yang selalu puasa setiap hari maka berpuasalah pada hari tersebut. (H.R. Bukhari, Muslim). ${ }^{24}$

23 Wahbah al-Zuhaylî, al-Fiqh al-Islâmî wa Adillatuh, (Damaskus: Dâr al-Fikr, 1989), Cet. ke-3, vol. 2, h. 598-604; Muhammad Buhait al-Muthî̂i, Irsyâd Ahl al-Millah ilâ Itsbât alAhillah (Mesir: Kurdistan al-'Ilmîyah, 1329), h. 12-22.

${ }^{24}$ Abû 'Abd Allah Muhammad bin Ismâ'îl al-Bukhari, alJâmi' al-Sahî li al-Bukhârî, (Kairo: Maktabah al-Salafîyah, 1403),
Hari yang belum jelas sebagai awal Ramadan atau akhir Sya'ban itu disebut hari yang masih meragukan. Sehingga mayoritas ulama mengharamkan puasa pada yawm al-syakk/puasa hari yang meragukan, yakni pada akhir bulan Sya'ban.25 Obyektifitas dalam menentukan dasar ibadah tentu lebih utama dari pada subyektifitas/zhann. Sebagaimana ungkapan Wahbah al-Zuhayli: "al'ilm muqaddam 'alâ al-zhann" bahwa pengetahuan yang pasti itu lebih diutamakan dari pada prasangka. ${ }^{26} \mathrm{Hal}$ ini sesuai dengan kaidah fikih:

$$
\text { اليَقِينُ لا يُزَالُ بِالشّكِّ }
$$

Keyakinan itu tidak bisa dihilangkan/digantikan dengan keraguan. ${ }^{27}$

\section{Subyektifitas Rukyatulhilal dan Perlunya Memadukan Dengan Sains}

Kesaksian terhadap ketampakan hilal merupakan salah satu faktor penting dalam penentuan bulan baru dalam kalender hijriah. Perburuan terhadap ketampakan hilal awal bulan bukan sesuatu yang mudah, sebab illuminasi hilal pada awal ketampakannya memang sangat lemah, sekitar 0,1\%. Sehingga bagi kalangan yang belum terlatih, mengindentifikasi keberadaannya tentu sangat sulit. Sehingga dalam praktiknya, subyektifitas masih sering dijumpi dalam kesaksian rukyatulhilal.

Contoh kasus pada tahun 1438, pada penentuan awal bulan Muharram. Data hisab yang mu'tabar menyebutkan variasi ketinggian hilal di Indonesia mulai $3^{\circ}-4,5^{\circ}$ (sudah di batas minimal imkân al-ru'yah MABIMS). NU dengan mazhab rukyat-nya menyatakan tidak berhasil melihat hilal dari seluruh lokasi rukyat yang tersebar di berbagai wilayah di seluruh Indonesia. Sehingga ikhbar awal bulan Muharram NU bertepatan tanggal 3 Oktober 2016 (sehari setelah Muhammadiyah dengan mazhab hisabnya). ${ }^{28}$

vol. 2, h. 34; al- Nawâwî, Sahîh Muslim bi Syarh al-Nawâwî, (Kairo: al-Mathba'ah al-Mishrîyah bi al-Azhar, 1929), vol. 7 h. 194.

${ }^{25}$ Muhammad al-Syarbînî al-Khatîb, al-lqnâ' fî Hilli Alfâdh Abî Syujâ', (Beirut: Dâr al-Fikr, 1415), vol. 1, h. 239.

${ }^{26}$ Wahbah bin Musthafâ al-Zuhaylî, al-Tafsir al-Munîr..., h.148.

27 Jalâl al-Dîn Abd al-Rahmân al-Suyûthî, al-Asybâh wa alNadhâir fi Qawâid wa Furû' Fiqh al-Syâfi'î, (Mekah: Maktabah Nizâr Musthafâ al-Bâz, 1997), vol. 1, h. 86.

28 "PBNU: Hilal Tak Terlihat, 1 Muharram 1438 H Jatuh Hari Senin | NU Online," diakses 19 Desember 2016, http://www. 
Subyektifitas justru tampak dari sebuah pengakuan kesaksian (syahâdah) dari salah satu ormas di Bekasi yang menyatakan berhasil melihat hilal secara kasat mata pada pukul 17:53 WIB. dengan ketinggian $6^{\circ}$ posisi miring ke selatan. Menurut laporan yang dibuat hilal awal Muharram 1438 berhasil disaksikan oleh tiga orang saksi yang diklaim sebagai saksi yang adil, yakni Syamsudin, Mubarrir, dan Saefuddin. ${ }^{29}$

Subyektifitas tampak dari dua sisi, baik hisab maupun rukyat. Dari sisi hisab bisa lihat dari ketidakjelasan model hisab yang dipakai sampai pada hasilnya yang berbeda jauh dengan hisab yang mu'tabar. ${ }^{30}$ Sedangkan dari sisi rukyat, selain tidak adanya bukti citra visual juga ketidaksesuaian kondisi cuaca, menurut laporan BMKG yang menyatakan seluruh wilayah di Indonesia mendung bahkan sebagian lagi hujan.

Hal serupa juga terjadi lagi pada bulan Shafar $1438 \mathrm{H}$. Data hisab yang mu'tabar menyatakan variasi ketinggian hilal di seluruh wilayah Indonesia antara $6,5^{\circ}-7,5^{\circ}$ (sudah diatas batas minimal imkân al-ru'yah). Namun data satelit cuaca menyatakan hampir seluruh wilayah Indonesia diselimuti awan. Awal bulan Safar memang tidak ada perbedaan. Namun subyektifitas masih tampak dari ikhbar NU yang didasari hasil persaksian satu orang an. Ust. H. Inwanuddin dari lokasi rukyat Tanjung Kodok Lamongan yang juga tidak disertai bukti citra visual.

Kasus serupa terjadi pada penentuan awal Ramadan $1437 \mathrm{H}$. Data hisab ${ }^{31}$ pada saat matahari terbenam hari Ahad Legi tanggal 5 Juni 2016 untuk seluruh wilayah Indonesia dengan variasi ketinggian antara $2^{\circ}$ sampai $4^{\circ}$. Ada laporan keberhasilan rukyat dari beberapa daerah di Indonesia, misalnya dari Bukit Condrodipo Gresik, Jombang, Bojonegoro, Kebumen dan Cakung. ${ }^{32}$

nu.or.id/post/read/71669/pbnu-hilal-tak-terlihat-1-muharram1438-h-jatuh-hari-senin

29 "al-jauharotunnaqiyyah ubi sahubi," diakses 28 November 2016, https://web.facebook.com/groups/245899648906786/ permalink/675585089271571

${ }^{30}$ Yang dimaksud hisab yang mu'tabar dalam artikel ini adalah sistem hisab kontemporer yang dipakai Kementerian Agama dan mayoritas organisasi kemasyarakatan di Indonesia, misalnya Ephemeris Hisab Rukyat dan Almanak Nautica.

${ }^{31}$ Sistem Informasi Falakiyah STAIN Ponorogo, (Ponorogo: Laboratorium Falakiyah STAIN Ponorogo, 2010).

32 Informasi dari group diskusi online jaringan
Berdasarkan laporan tersebut Kementerian Agama meng-itsbât-kan awal Ramadan 1437 H. jatuh pada hari Senin Pahing, 6 Juni 2016. NU juga meng-ikhbar-kan awal Ramadan 1437 H. pada hari tersebut. Namun persaksian dari berbagai daerah tersebut juga masih belum didukung bukti empiris berupa citra hilal.

Menurut penelitian seorang astronom Islam dari King Saud University, bahwa selama 40 tahun hasil rukyatulhilal yang diumumkan oleh pemerintah Saudi Arabia, 87\% adalah salah dan tidak dapat dipertanggungjawabkan secara ilmiah. ${ }^{33}$ Hilal memang obyek yang bersifat fisis yang mungkin ditangkap oleh indra penglihatan manusia. Maka menilai kebenaran rukyatulhilal bisa didasarkan pada teori korespondensi, yaitu mendapatkan kebenaran berdasarkan tangkapan pancaindranya. ${ }^{34}$ Namun, hilal merupakan obyek fisis yang sangat redup, sehingga informasi yang diterima oleh indra penglihatan juga patut untuk dipertanyakan kebenarannya. Sehingga bukti material sangat diperlukan dalam menguatkan informasi yang diterima oleh indra penglihatan manusia. Bukti material ini diperlukan untuk meminimalisir kesalahan yang sangat mungkin terjadi dalam pelaksanaan rukyatulhilal. Sehingga ketika sidang itsbât penentuan awal bulan hijriah dilaksanakan, hakim mempunyai bukti yang tidak meragukan lagi untuk dijadikan dasar membuat keputusan.

Untuk saat ini, menyertakan bukti citra hilal di samping data hilal menurut penulis merupakan sebuah keniscayaan. Ilmu dan teknologi sudah berkembang sedemikian pesat. Bukti ilmiah sangat diperlukan untuk menjamin kepastian syahâdah yang dijadikan pedoman itsbât awal bulan Ramadhân dan Syawwal. Oleh karena itu mengkonfirmasi kejujuran dan 'adâlah saksi dalam rukyatulhilal dengan bukti ilmiah sangat diperlukan, untuk menghindarkan kekeliruan

\footnotetext{
pelaksana rukyat Lembaga Falakiyah NU melalui media WhatsApp (WA) dengan nama group Hilal Record.

${ }^{33}$ Susiknan Azhari, "Penyatuan Kalender Islam: "Mendialogkan Wujûd al-Hilâl dan Visibilitas Hilal," AHKAM: Jurnal Ilmu Syariah, Vol, 13, No. 2, 2013, h.161, http://journal.uinjkt.ac.id/index. php/ahkam/article/view/931

${ }^{34}$ Bustanuddin Agus, Integrasi Sains dan Agama, Tinjauan Filsafat Ilmu Kontemporer, (Jakarta: Universitas Indonesia Press, 2013), h. 35.
} 
dalam mengidentifikasi obyek yang dilihat oleh saksi rukyatulhilal. Saat ini, sumpah terhadap saksi merupakan dasar utama dalam penerimaan kesaksian melihat hilal. Namun dalam praktiknya, hampir tidak pernah ada klarifikasi terhadap syarat-syarat terpenuhinya kesaksian hilal. Sebab ternyata dalam praktik di lapangan, sebagaimana pemaparan Thomas Djamaluddin, masih banyak yang belum bisa mengidentifikasi dengan pasti apakah yang dilihat hilal atau obyek lain. ${ }^{35}$

Menurut penulis, tidak selayaknya seorang hakim dengan serta merta menerima kesaksian melihat hilal, dengan proses penyumpahan. Upaya klarifikasi terhadap kebenaran yang dilihat saksi sangat perlu dilakukan. Para fuqahâ' sendiri telah menentukan beberapa kriteria terhadap saksi, tentu 'illat yang yang dibangun adalah demi terpenuhinya sisi obyektifitas kesaksian. Hilal yang bersifat fisis, harus dilihat dan dibuktikan secara fisis pula. Sangat janggal ketika obyektifitas ketampakannya hanya didasarkan pada sebuah sumpah terhadap saksi (yang dianggap adil) yang pada praktiknya hampir tidak pernah diklarifikasi tentang terpenuhi tidaknya syarat sebagai seorang saksi yang telah ditetapkan oleh fuqaha'. Mengukur 'adâlah seorang saksi memang tidak mudah, namun syarat tersebut sudah ditetapkan oleh fuqahâ' yang tentu harus dipenuhi ketika hendak menerima kesaksian. Untuk saat ini, memenuhi unsur obyektifitas dari seorang saksi bisa dibantu dengan penggunaan sains dan teknologi. Penyertaan bukti ilmiah dari kesaksian hilal berupa data dan citra hilal menurut penulis sangat diperlukan dalam rangka meningkatkan obyektitas syahâdah/kesaksian dalam rukyatulhilal.

\section{Penggunaan Teknologi Optik dan Image Detector}

Mengenali ketampakan hilal memang bukan sesuatu yang mudah, oleh karena itu dalam kegiatan rukyatulhilal, perlu dipersiapkan berbagai perlengkapan untuk membantu efektifitas dan optimalisasi tercapainya tujuan rukyatulhilal, yakni keberhasilan melihat hilal. Perlengkapan tersebut meliputi data perhitungan

35 T. Djamaluddin, Menggagas Fiqih Astronomi, (Bandung: Kaki Langit, 2005), h. 19. yang menjelaskan kondisi hilal, baik posisi maupun ketinggiannya, juga berbagai peralatan yang digunakan untuk membantu melokalisir pandangan dan memperjelas obyek. Salah satu alat yang umumnya dipakai adalah teleskop.

Teleskop atau mirqab adalah sebuah perangkat optik yang digunakan untuk menambah kemampuan mata dalam melihat benda yang jauh atau yang redup, khususnya benda langit. ${ }^{36}$ Secara umum teleskop terdiri dari dua bagian, yaitu tabung optik yang disebut optical tube dan dudukan penggerak tabung optik yang disebut mounting.

Bagian pertama, optical tube atau tabung optik teleskop, yaitu instrumen optik yang berfungsi mengumpulkan lebih banyak cahaya ke mata dan dapat memperbesar serta memperjelas objek yang jauh. ${ }^{37}$ Optik teleskop terdiri dari dua bagian, yaitu objektif dan okuler. Objektif berfungsi memusatkan cahaya obyek pada satu titik api atau fokus. Okuler berfungsi menangkap cahaya yang sudah terpusat tersebut.

Menurut Agustinus Gunawan Admiranto, fungsi pokok teleskop adalah mengumpulkan cahaya, memperbesar bayangan, dan memperbesar daya pisah..$^{38}$ Fungsi utama teleskop secara lebih detail menurut A.E. Roy dan D. Clarke antara lain:

1. Untuk memungkinkan pengumpulan cahaya yang mencakup area yang lebih besar sehingga objek yang samar dapat dideteksi dan diukur dengan lebih akurat.

2. Untuk memungkinkan tercapainya sudut resolusi yang lebih tinggi sehingga pengukuran posisi dapat dibuat lebih akurat dan rinci sehingga informasi mengenai objek benda langit dapat direkam. ${ }^{39}$

Sesuai dengan cara kerjanya, ada tiga jenis utama teleskop optik yang digunakan yaitu Refraktor atau Dioptrik, Reflektor atau Katoptrik

${ }^{36}$ Patrick Moore, ed., Philip's Astronomy Encyclopedia, Fully rev. and expanded ed, (London: Philip's, 2002), 402; Khazin, Kamus Ilmu Falak, h. 56.

37 Robbin Kerrod, Bengkel Ilmu Astronomi, terj. Syamaun Peusangan, (Jakarta: Penerbit Erlangga, 2005), h. 6.

${ }^{38}$ Agustinus Gunawan Admiranto, Menjelajahi Bintang Galaksi dan Alam Semesta, (Yogyakarta: Kanisius, 2009), h. 8.

39 A. E. Roy dan D. Clarke, Astronomy: Principles and Practices, (Bristol: J. W. Arrowsmith, 1978),h. 233. 
dan Catadioptric. Jenis pertama teleskop optik adalah refraktor atau dioptrik. Yaitu teleskop yang hanya menggunakan lensa untuk menampilkan bayangan benda. Teleskop refraktor merupakan jenis teleskop pertama kali yang ditemukan dari ketiga jenis teleskop yang ada. Jenis teleskop ini digunakan untuk pertama kalinya di Belanda oleh tiga orang yaitu Hans Lippershey, Zacharias Janssen dan Jacob Metius. Kemudian dari teleskop yang ada, oleh Galileo Galilei dikembangkan desain nya dan disusul pula oleh Johannes Kepler dengan desain yang berbeda sehingga dari desain kedua orang ini muncul desain yang akan sering kita dengar yaitu teleskop refraktor Galilean dan Keplerian.

Prinsip dari semua teleskop refraktor pada umumnya sama yaitu dengan menggunakan kombinasi dua buah lensa, objektif dan okuler. Lensa obyektif/utama berfungsi sebagai pengumpul bayangan dan cahaya kemudian diteruskan ke lensa mata/okuler atau yang disebut dengan eyepiece, untuk ditampilkan ke mata sebagai bayangan dari sebuah benda. Tujuan dari teleskop refraktor adalah membiaskan atau membelokkan cahaya. Refraksi ini menyebabkan sinar cahaya paralel berkumpul pada titik fokus. Teleskop akan mengkonversi seikat sinar sejajar dengan membuat sudut alpha. Dengan sumbu optik untuk sebuah kumpulan sinar paralel kedua dengan sudut beta. Rasio beta berbanding alpha disebut sudut pembesaran. Ini sama dengan perbandingan antara ukuran gambar retina diperoleh dengan dan tanpa teleskop. ${ }^{40}$

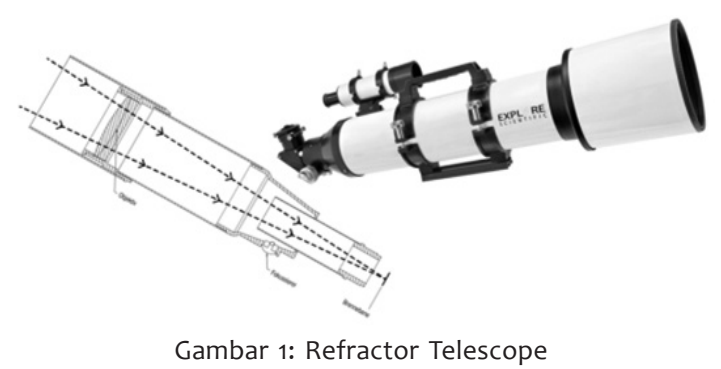

Jenis kedua adalah reflektor atau katoptrik. Yaitu jenis teleskop yang menggunakan cermin

${ }^{40}$ Dinah L. Moche, Astronomy a Self-Teaching Guide, 7 ed. (New Jersey: John Wiley \& Sons Inc., 2009), h. 40-44. Bandingkan http://kafeastronomi.com/mengenal-jenis-jenisteleskop.html (diakses 10 Februari 2018). untuk memantulkan cahaya dan bayangan benda. Dari namanya, bisa diketahui bahwa reflektor berasal dari kata refleksi yang artinya memantulkan. Teleskop reflektor adalah teleskop yang menggunakan satu atau kombinasi dari cermin lengkung yang merefleksikan cahaya dan bayangan gambar. Teleskop reflektor merupakan teleskop alternatif dari teleskop refraktor karena kelainan cacat kromatik yang ditimbulkan oleh lensa. Meskipun teleskop reflektor menghasilkan kelainan optik lainnya, desain reflektor memungkinkan untuk pengembangan dengan diameter yang cukup besar.

Teleskop reflektor lebih cocok digunakan untuk pengamatan objek-objek deepsky seperti nebula, galaksi, opencluster dan comet karena untuk "light gathering" teleskop reflektor jauh lebih baik daripada teleskop refraktor sehingga untuk objek-objek yang mempunyai intensitas cahaya kecil dapat terlihat dengan reflector.

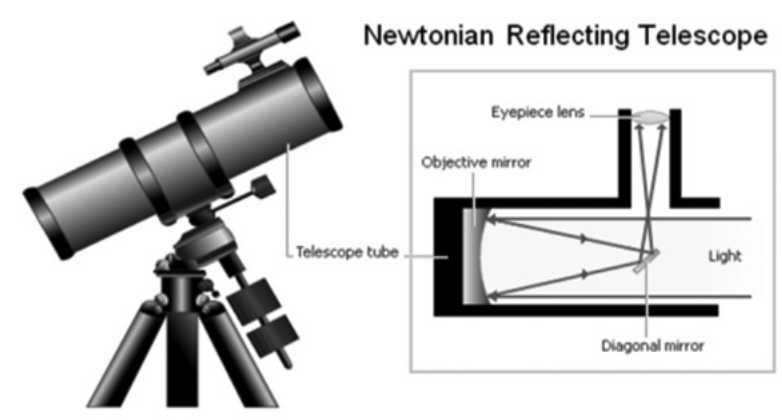

Gambar 2: Reflector Telescope

Sedangkan jenis yang ketiga adalah Catadioptric. Yaitu jenis teleskop yang menggunakan kombinasi dari lensa dan cermin sebagai pengumpul cahaya sekaligus bayangan benda. Teleskop jenis ini adalah implementasi dari penggunaan sistem catadioptric yaitu sebuah sistem yang memadukan penggunaan antara lensa dan cermin lengkung. Dengan kata lain teleskop catadioptric merupakan jenis teleskop gabungan dari refraktor dan reflektor disatu sisi menggunakan cermin di sisi lain menggunakan lensa. Lebih simpel nya pengertian dari Teleskop Catadioptric adalah teleskop yang memadukan lensa dan cermin. Sistem ini tidak hanya diterapkan pada teleskop saja, tetapi diterapkan juga pada mikroskop, dan lensa tele pada kamera. 

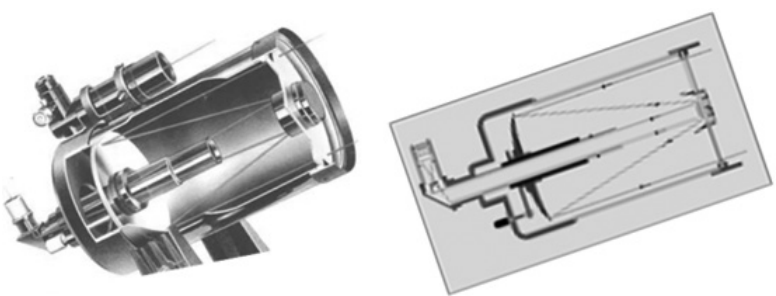

Gambar 3: Catadioptric Telescope

Seiring perkembangan teknologi, peran teknologi image detector baik yang berupa kamera dengan segala macam jenisnya, maupun image sensor yang biasa dikenal dengan sebutan digital eyepiece, sangat penting dalam membantu meningkatkan kualitas rukyatulhilal. Image detector berfungsi menangkap obyek yang menjadi target teleskop dan merubahnya menjadi citra gambar untuk disimpan dan selanjutnya bisa dianalisis dan dipergunakan sesuai keperluan. Sebelum dipergunakannya image detector dalam teleskop, pengamatan dilakukan dengan melihat secara langsung ke lensa okuler atau yang disebut eyepiece. Kelebihan dari penggunaan eyepiece, adalah kemudahan dalam penyesuaian sudut pandang teleskop sesuai yang dikehendaki dengan mengubah ukurannya. Namun kekurangannya lensa okuler/eyepiece hanya bisa menangkap obyek saja tanpa bisa merekam apalagi menyimpan obyek yang dibidik.

Bagian kedua dari teleskop adalah mounting, yaitu dudukan teleskop yang fungsinya selain sebagai penopang juga yang mengatur pergerakan teleskop dalam membidik obyek. Dari system kerjanya, mounting atau yang lebih familiar dikenal dengan dudukan teleskop terbagi dalam 2 jenis yaitu jenis mounting equatorial dan jenis mounting altazimuth. ${ }^{41}$ Sedangkan dari sisi penggeraknya mounting/dudukan teleshop ada 2 macam, yakni manual dan computerized.

Mounting Equatorial bekerja menggunakan 3 buah sumbu yaitu sumbu RA, Deklinasi dan Equator. Sedang mounting altazimuth menggunakan 2 buah sumbu yaitu sumbu $x$ atau altitude (atas bawah) dan $\mathrm{Y}$ atau azimuth (kanan kiri).

${ }^{41}$ Jingquan Cheng, The Principles of Astronomical Telescope Design, (New York: Springer, 2008), h. 141; Pierre Y. Bely, ed., The Design and Construction of Large Optical Telescopes, (New York: Springer, 2002), h. 233.
Untuk pengoperasian mounting altazimuth jauh lebih mudah dibanding mounting equatorial. Sistem altazimuth lebih gampang, tinggal pasang di lokasi manapun, sepanjang kita tahu lokasi koordinat, (lebih mudah kalau sudah dilengkapi GPS), tinggal jalan tracking.

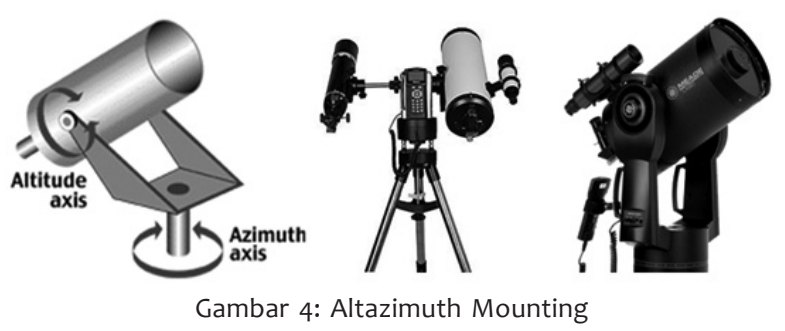

Sistem ekuatorial agak lebih rumit karena selain kita harus tahu posisi pengamat, kita juga harus atur arah utara-selatan-timur-barat teleskop, lebih presisi lebih baik; tapi bila itu sudah dikerjakan dengan baik, untuk mengikuti gerak benda langit akan menjadi jauh lebih mudah, ada atau tidak ada mesin, karena kita hanya bekerja pada satu sumbu teleskop.

Mounting manual digerakkan secara manual dan tidak bisa melakukan tracking obyek yang dituju. Sedangkan computerized mounting adalah dudukan teleskop yang bergerak secara otomatis dengan program. Sehingga bisa melakukan tracking terhadap obyek yang dibidik. Saat ini computerized mounting sudah banyak yang dilengkapi dengan GPS (Global Positioning System) sehingga pengguna tidak perlu lagi melakukan input data koordinat tempat untuk melakukan tracking.

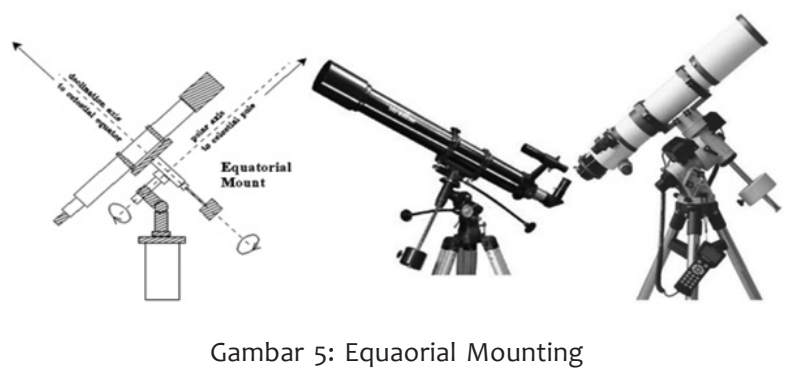

\section{Penggunaan Teknologi Digital Imaging}

Tidak kalah pentingnya dengan teknologi optik yang berfungsi mengumpulkan cahaya dan teknologi pendeteksi citra yang berfungsi menangkap citra dan menyimpannya, teknologi digital imaging juga memegang peranan sangat 
signifikan dalam mengolah dan menganalisa citra yang dihasilkan. Teknologi ini berupa software yang bisa digunakan untuk berbagai keperluan, baik peningkatan kualitas citra obyek maupun untuk menganalisa citra tersebut.

Keberadaan teknologi ini bisa dimanfaatkan secara maksimal dalam kegiatan rukyatulhilal. Dengan teknologi ini, kontras cahaya hilal yang sangat lemah, bahkan tidak terlihat oleh mata bisa meningkat sehingga bisa dengan mudah dilihat. Sehingga dengan penguasaan terhadap teknologi ini perburuan terhadap sinar hilal yang sangat lemah tersebut bisa terbantu dengan tingkat akurasi dan obyektifitas yang bisa dipertanggunjawabkan.

Software untuk keperluan digital imaging ini banyak sekali macamnya, mulai dari yang opensource sampai yang berbayar. Sebagai contoh, berikut penulis sampaikan teknik yang paling sederhana dalam pengolahan citra dalam rangka meningkatkan kontras sinar hilal yang sangat lemah dan tipis, yang tidak bisa terlihat oleh mata sehingga menjadi mudah dilihat dan dkenali. Dalam contoh ini, penulis menggunakan salah satu opensource software yang bisa dengan mudah diunduh dari internet dengan kapasitas file cukup kecil dan operasionalnya lumayan mudah. ${ }^{42}$

Adapun langkah-langkah dalam pengolahan citra menggunakan software tersebut adalah sebagai berikut:

\section{Menyiapkan rekaman citra hilal}

Rekaman citra hilal dilakukan dengan menggunakan teleskop, diutamakan jenis refraktor dan computerized mount dengan fokal rasio yang rendah, karena diameter lengkung hilal lumayan besar. Selain teleskop, beberapa perlengkapan yang harus disiapkan adalah filter matahari, image detector/digital eyepiece diutamakan yang monokrom, laptop dengan spesifikasi gaming, dan software interface. ${ }^{43}$

Sebelum proses perekaman dimulai teleskop

${ }^{42}$ Software ini diberi nama Iris, dan dapat dilihat dan di unggah melalui www.astrosurf.com/buil/us/iris/iris.htm .

${ }^{43}$ Misalnya Sharpcap, yang bisa dilihat dan diunggah melalui www.sharpcap.co.uk harus dikalibrasi, untuk memastikan akurasinya dalam membidik obyek. Sebab obyek hilal yang akan direkam merupakan obyek yang sangat redup dan belum tentu bisa diamati dengan mata. Kalibrasi/alignment teleskop minimal dilakukan saat matahari belum terbenam, dengan mengarahkan teleskop yang sudah dipasangi filter matahari ke arah matahari. Setelah teleskop mengarah ke matahari, selanjutnya teleskop disynchronize dengan memposisikan matahari tepat di tengah medan pandang eyepiece dengan mengatur fokusnya sebaik mungkin. Penggunaan baffle sangat disarankan, untuk meningkatkan fokus teleskop dan mereduksi sinar yang tidak diperlukan untuk ditangkap lensa obyektif. ${ }^{44}$ Setelah itu eyepiece diganti dengan digital eyepiece dan siap untuk merekam obyek sesuai kebutuhan. Rekaman obyek berupa file video dengan format avi. Semakin banyak file dan frame yang disimpan akan semakin baik, dengan konsekuensi semakin banyak kapasitas hard disk yang dibutuhkan.

\section{Pengolahan rekaman citra hilal ${ }^{45}$}

Setelah rekaman citra hilal didapatkan, maka data tersebut siap diolah menggunakan software Iris. Setelah software dijalankan, yang pertama dilakukan adalah mengatur direktori penyimpanan hasil pekerjaan, dan tipe file yang dipilih (pilih tipe file fit). Langkahnya adalah, pilih File -- Setting -- Working Path (pilih pada drive mana pekerjaan disimpan) -- File Type: FIT -- Command Window: Multiple -- OK.

${ }_{44}$ Baffle adalah sebuah tabung yang didalamnya ada beberapa sirip dengan konfigrasi tertentu yang diletakkan di depan lensa obyektif dengan tujuan untuk mengurangi sudut cahaya, sehingga cahaya liar yang tidak dikehendaki bisa diminimalisir, sehingga kontras cahaya obyek yang dibidik bisa ditingkatkan. Dhani Herdiwijaya, Mitra Djamal, dan Hendra Gunawan, "Design of Mobile and Robotic Observing System with Special Telescope Baffle for Searching Young Lunar Crescent," Jurnal Otomasi, Kontrol, dan Instrumentasi, Vol. 4, No. 1, 2012, h.3.

${ }^{45}$ Bukti rekaman ini adalah bukti otentik yang bisa dilacak data scriptnya. Sehingga ketika hendak menjadikan image hasil konversi yang diolah dengan teknik digital imaging sebagai bukti ketampakan hilal, file rekaman asli juga harus dilampirkan sebagai bahan utama yang bisa dipertanggungjawabkan kebenaran data scriptnya. 


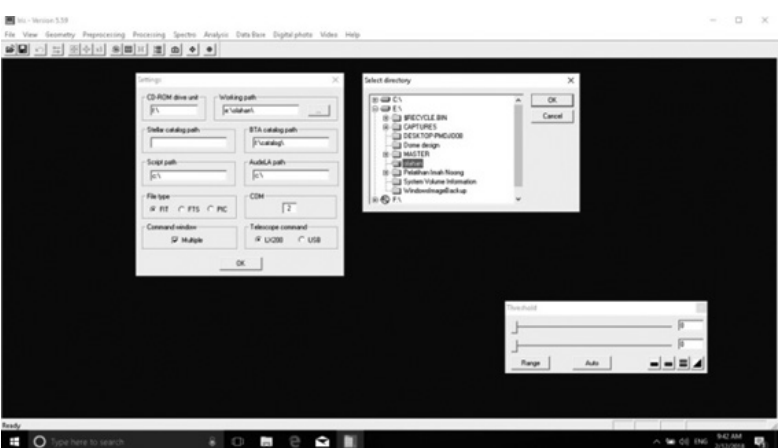

Gambar 6: Setting Working Path Iris

Langkah berikutnya adalah mengkonversi hasil rekaman citra hilal yang dalam format video ke dalam format image (fit). Hasil konversi ini berupa image/foto yang jumlahnya banyak sesuai dengan pengaturan frame rate dan durasi perekaman yang dilakukan. Sebagai gambaran, misalnya dalam satu file rekaman frame rate yang dikehendaki adalah 50 frames detik, ketika durasi rekaman adalah 3 detik, maka jumlah image yang dihasilkan adalah $50 \times 3$ yakni 150 image/foto. Yang perlu diingat, bahwa dalam satu kegiatan rukyat, tentu tidak hanya satu file video yang dihasilkan. Semakin banyak rekaman yang dihasilkan semakin leluasa untuk memilih yang terbaik.

Untuk praktik kali ini penulis menggunakan hasil observasi Hendro Setyanto, owner Imah Noong Observatory Bandung, yang merupakan hasil observasi/rukyatulhilal awal Ramadan tahun $1436 \mathrm{H}$ pada tanggal 17 Juni 2016 pukul 17:47 WIB di menara JICA Universitas Pendidikan Indonesia Bandung. Sebelum melihat hasil akhir dari proses ini, berikut adalah screenshoot dari rekaman tersebut sebagai pembanding untuk membuktikan peningkatan kontras hilal yang direkam. Dari hasil rekaman tersebut diketahui bahwa hilal tidak kasat mata.
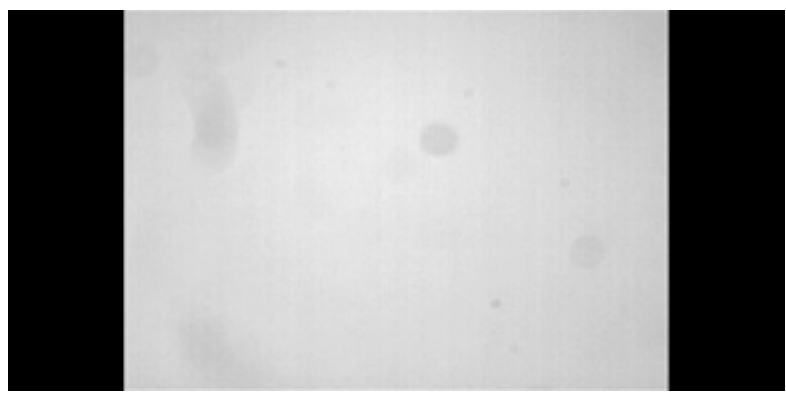

Gambar 7: Screenshoot rekaman hilal
Setelah salah satu file avi dipilih dan siap dikonversi, kita tentukan tipe calon image sesuai jenis kamera/digital eyepiece yang digunakan dalam proses perekaman. Kalau jenis monokrom, maka tipe image yang dipilih black \& white, sedangkan yang jenis color bisa memilih tipe image color atau black \& white. Setelah itu namai calon image hasil konversi tersebut. Langkahnya adalah, pilih File -- AVI Conversion -- Select (file yang akan dikonversi) -- Exported Image Type: pilih Color atau Black \& White -- File Name -Convert.

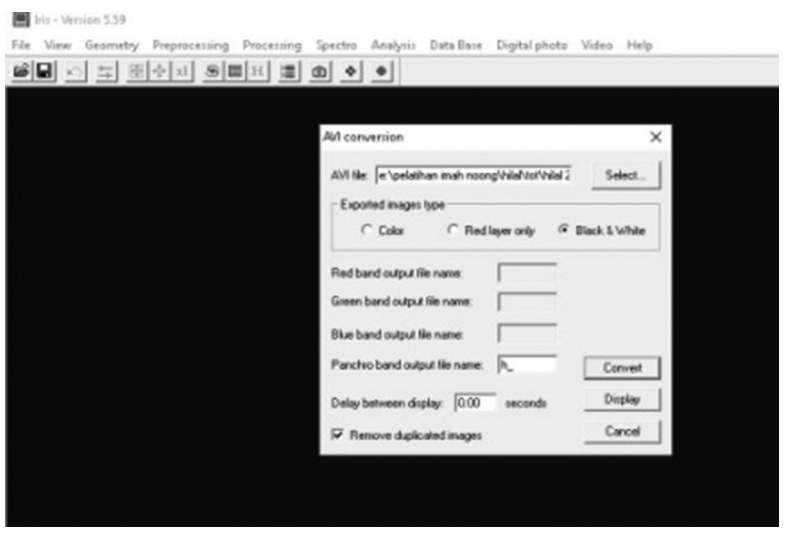

Gambar 8: Langkah konversi file video ke image

Setelah siap, ikuti proses konversi sampai selesai, yang lamanya bervariasi sesuai jumlah frames yang dikonversi dan spesifikasi komputer yang dipergunakan. Setelah proses konversi selesai, software akan mengkonfirmasi jumlah frame yang berhasil dikonversi menjadi image. Dari sejumlah image tersebut, selanjutnya bisa ditentukan urutan image mana saja yang akan distacking/dijumlahkan menjadi satu. Semakin banyak jumlah image image yang distacking, akan diperoleh kontras yang semakin besar sehingga akan menghasilkan image yang lebih tajam. Setelah semua proses selesai, layar komputer hanya akan tampak warna putih, maka sebagai langkah finishing kita atur nilai threshold baik secara manual maupun auto untuk mendapatkan hasil akhir yang dimaksud. Sampai di sini image bisa disimpan dengan variasi tipe image. Langkahnya adalah, pilih Processing -- add sequence -- input generic name (diisi sesuai nama yang dikehendaki) -- Number (jumlah image yang hendak distacking) -- type: Arithmatic -- Ok -Threshold (digeser manual atau Auto) -- Save As. 


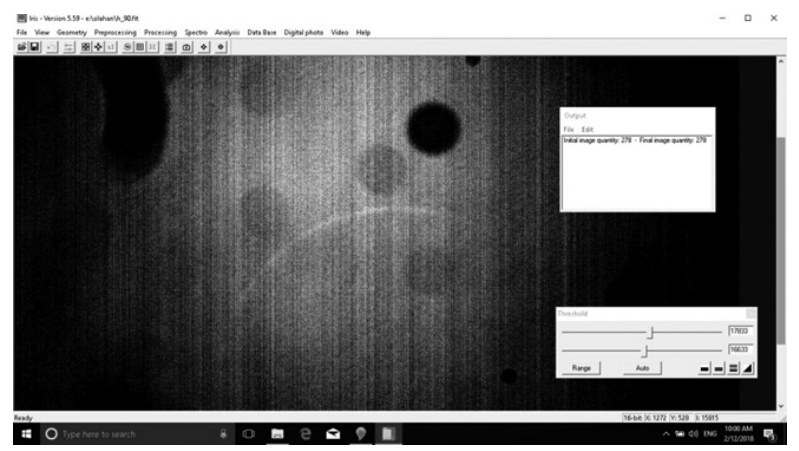

Gambar 9: Hasil akhir proses stacking

Contoh di atas adalah stacking sejumlah 100 frames dari 278 frames yang dikonversi dari video. Pada prinsipnya semakin banyak jumlah frame yang distacking maka tingkat ketajaman image yang dihasilkan akan semakin tinggi. Dari contoh di atas, bisa diketahui posisi hilal dalam keadaan terbalik, ini adalah konsekuensi logis dari penggunaan teleskop refraktor yang bersifat membalik obyek. Hal ini bisa diatasi dengan penggunakan erecting prism pada teleskop, dan bisa juga dengan merubah setting pada kamera atau digital eyepiece sebelum proses perekaman. Proses ini merupakan salah satu proses yang paling sederhana, namun hasil yang didapatkan lumayan memuaskan. Pada tahap yang lebih detail lagi, selain meningkatkan ketajaman image bisa juga dilakukan proses pembersihan terhadap image dari kotoran-kotoran yang diakibatkan oleh debu atau partikel yang menempel pada lensa maupun digital eyepiece, tentu dengan langkah yang lebih panjang.

Dari sini nampak sekali bahwa proses digital imaging yang dilakukan sangat berdampak pada peningkatan kontras hilal, dari yang semula tidak kasat mata menjadi sangat jelas dan bisa dikenali dengan mudah oleh orang awam sekalipun. Sehingga proses digital imaging ini menghasilkan obyek hilal yang sangat obyektif, yang bisa bisa dilihat oleh siapa saja, bisa dianalisis dan dipertanggung jawabkan kebenarannya.

Kegiatan rukyatulhilal yang disertai dengan proses digital imaging mempunyai beberapa kelebihan dibandingkan dengan kegiatan yang sama dengan peralatan yang sama, tetapi tidak disertai dengan proses digital imaging. Kelebihan tersebut antara lain:

- Proses digital imaging bisa menampilkan kontras citra yang jauh lebih bagus dari pada citra asli yang belum diproses;

- Citra hasil proses digital imaging tidak menimbulkan keraguan, baik ketika hilalnya terlihat maupun sebaliknya.

\section{Penutup}

Meskipun tidak ada dalil yang mengharuskan penggunaan teknologi rukyat, baik yang bersifat membantu penglihatan maupun mengolah citra yang ditangkap alat bantu rukyat, namun pemanfaatan teknologi ini dalam kegiatan rukyatulhilal dan lampiran bukti citra hilal dalam syahâdah rukyatulhilal menjadi suatu keniscayaan. Sebab sampai saat ini masih sering kali terdapat syahâdah kontroversial yang bertentangan dengan data hisab dan kondisi kecerlangan atmosfir. Syahâdah rukyatulhilal yang menjadi dasar itsbât awal bulan harus berdasarkan bukti yang jelas, sebagaimana tersirat dalam hadis Nabi.

Sains dan teknologi, khususnya dalam bidang optik dan digital imaging terbukti bisa membantu meningkatkan obyektifitas dalam kesaksian rukyatulhilal. Penggunaan teknologi ini diharapkan menjadi salah satu syarat tambahan dalam penerimaan syahâdah rukyatulhilal demi meningkatkan kualitas dan obyektifitasnya dan dapat dipertanggungjawabkan kebenarannya dari sisi fikih dan sains sebagai dasar penetapan awal bulan Hijriyah.

\section{Pustaka Acuan}

'Askarî, Abû Hilâl al-hasan bin 'Abdillâh bin Sahal bin Sa'îd bin Yahyâ bin Mahrân al-, Mu'jam al-Furûq al-Lughawîyah, Muassasah al-Nasyr al-Islâmî, 1412.

Admiranto, Agustinus Gunawan, Menjelajahi Bintang Galaksi dan Alam Semesta, Yogyakarta: Kanisius, 2009.

Agus, Bustanuddin, Integrasi Sains dan Agama, Tinjauan Filsafat Ilmu Kontemporer, Jakarta: Universitas Indonesia Press, 2013.

"al-jauharotunnaqiyyah ubi sahubi," diakses 28 November 2016,https://web.facebook. com/groups/245899648906786/ permalink/675585089271571.

Ali, Atabik dan Ahmad Zuhdi Muhdlor, Kamus Kontemporer Arab-Indonesia, Yogyakarta: Multi Gaya Grafika, 1998. 
Azhari, Susiknan, "Penyatuan Kalender Islam: "Mendialogkan Wujûd al-Hilâl dan Visibilitas Hilal," AHKAM: Jurnal Ilmu Syariah, Vol, 13, No. 2, 2013, h.161, http://journal.uinjkt.ac.id/ index.php/ahkam/article/view/931

Azhari, Susiknan, Ensiklopedi Hisab Rukyat, Yogyakarta: Pustaka Pelajar, 2008.

Badan Hisab dan Rukyat Departemen Agama, Almanak Hisab Rukyat, Jakarta: Direktorat Bimbingan Masyarakat Islam Kementerian Agama RI, 2010.

Bukhari, Abû 'Abd Allah Muhammad bin Ismâ'îl al-, al-Jâmi' al-Sahî li al-Bukhâarî, Kairo: Maktabah al-Salafîyah, 1403, vol. 2.

Cheng, Jingquan The Principles of Astronomical Telescope Design, New York: Springer, 2008.

D Moche, inah L. Astronomy a Self-Teaching Guide, 7 ed., New Jersey: John Wiley \& Sons Inc., 2009.

Dâwud, Abû, Sunan Abî Dâwud, Beirut: Dâr alFikr, tt, vol. 1.

Departemen Agama RI, Pedoman Teknik Ru'yat, Jakarta: Proyek Pembinaan Badan Peradilan Agama, 1994.

Djamaluddin, Moore T, Menggagas Fiqih Astronomi, Bandung: Kaki Langit, 2005.

Djamaluddin, Thomas, Astronomi memberi Solusi Penyatuan Ummat, Jakarta: Lembaga Penerbangan dan Antariksa Nasional, 2011.

Fayyûmî, Ahmad bin Muhammad bin 'Alî al-Maqrî al-, al-Mishbâh al-Munîr fî Gharîb al-Syarh al-Kabîr li al-Râfîi, Beirut: al-Maktabah al'Ilmîyah, tt.

Herdiwijaya, Dhani, Mitra Djamal, dan Hendra Gunawan, "Design of Mobile and Robotic Observing System with Special Telescope Baffle for Searching Young Lunar Crescent," Jurnal Otomasi, Kontrol, dan Instrumentasi, Vol. 4, No. 1, 2012.

Kerrod, Robbin, Bengkel Ilmu Astronomi, terj. Syamaun Peusangan, Jakarta: Penerbit Erlangga, 2005

Khatîb, Muhammad al-Syarbînî al-, al-Iqnâ' fî Hilli Alfâdh Abî Syujâ', Beirut: Dâr al-Fikr, 1415, vol. 1. Khazin, Muhyiddin, Kamus Ilmu Falak, Yogyakarta: Buana Pustaka, 2005.

Ma'luf, Louis, al-Munjid fî al-Lughah wa al-A'lâm, Beirut: Dâr al-Masyriq, 1989.

Manzûr, Ibnu, Lisân al-'Arab, Kairo: Dâr al-Ma'ârif, tt, vol. 17 .
Masroerie, A. Ghazali, Penentuan Awal Bulan Qamariyah, Jakarta: Lajnah Falakiyah Nahdatul Ulama, 2011.

Munawwir, Ahmad Warson, al-Munawwir Kamus Arab-Indonesia, Surabaya: Pustaka Progresif, 1997.

Muthî̀, Muhammad Buhait al-, Irsyâd Ahl alMillah ilâ Itsbât al-Ahillah, Mesir: Kurdistan al-'llmîyah, 1329.

Nasâî, al-, Sunan al-Nasâi., Beirut: Dâr al-Fikr, tt, vol. 4 .

Nawâwî, al-, Sahîh Muslim bi Syarh al-Nawâwî, Kairo: al-Mathba'ah al-Mishrîyah bi al-Azhar, 1929, vol. 7 .

Patrick, ed., Philip's Astronomy Encyclopedia, Fully rev. and expanded ed, London: Philip's, 2002.

"PBNU: Hilal Tak Terlihat, 1 Muharram 1438 H Jatuh Hari Senin | NU Online," diakses 19 Desember 2016, http://www.nu.or.id/post/ $\mathrm{read} / 71669 / \mathrm{pbnu}$-hilal-tak-terlihat-1-muharram1438-h-jatuh-hari-senin

Pierre Y. ed., The Design and Construction of Large Optical Telescopes, New York: Springer, 2002.

Raharto, Moedji, “Teknologi Optik sebagai Pembantu Penetapan Awal Bulan Hijriah/ Qamariyah," dalam Hisab Rukyat dan Perbedaannya, ed. oleh Choirul Fuad Yusuf, Jakarta: Puslitbang Kehidupan Beragama Badan Litbang Agama dan Diklat Keagamaan Departemen Agama RI, 2004.

Râzî, Muhammad bin Abî Bakr al-, Mukhtâr alSihâh, Kairo: Dâr al-Hadîts, 2003.

Roy, A. E. dan D. Clarke, Astronomy: Principles and Practices, Bristol: J. W. Arrowsmith, 1978.

Salam, Abd., Penentuan Awal Bulan Islam dalam Tradisi Figh Nahdatul Ulama, Surabaya: Pustaka Intelektual, 2009.

Sistem Informasi Falakiyah STAIN Ponorogo, Ponorogo: Laboratorium Falakiyah STAIN Ponorogo, 2010.

Suyûtî, Jalâl al-Dîn Abd al-Rahmân al-, al-Asybâh wa al-Nadhâir fi Qawâid wa Furû' Fiqh al-Syâfi'î, Mekah: Maktabah Nizâr Musthafâ al-Bâz, 1997, vol. 1.

Sya'râwî, Muhammad Mutawallî al-, Tafsîr alSya'râwî, Akhbâr al-Yawm, 1991, vol. 2. 
Syarwânî, 'Abd al-Hamîd al-, Hawâsyî Tuhfah alMuhtâj bi Syarh al-Minhâj, Kairo: Muhammad, Mathba'ah Musthafâ, Ahmad Izzuddin, Fiqh Hisab Rukyah, Jakarta: Erlangga, t.t 2007, vol. 3.

Tâliqânî, Abû al-Qâsim Ismâ'îl bin 'Ubbâd bin al'Abbâs bin Ahmad bin Idrîs al-, al-Muhîth fî
al-Lughah, Beirut: 'Alim al-Kutub, 1994, vol. 3. Tirmîdhî, Al-, al-Jâmi' al-Shahîh, Beirut: Dâr alFikr, tt, vol. 3 .

Zuhaylî, Wahbah bin Musthafâ al-, al-Tafsir alMunîr fî al-'Aqîdah wa al-Syarî'ah wa al-Manhaj, Damaskus: Dâr al-Fikr al-Mu'âsir, 1418, vol. 2. -----, al-Fiqh al-Islâmî wa Adillatuh, Damaskus: Dâr al-Fikr, 1989, Cet. ke-3, vol. 2. 